\title{
Influence of Particle Size of Fine Aggregate on Filling Ability and Segregation Resistance of Self- Compacting Concrete
}

\author{
Er. Ankush Gupta ${ }^{1}$, Dr. Rajeev Chandak ${ }^{2}$ and Prof. M.K. Koshta ${ }^{3}$ \\ Department of Civil Engineering, Jabalpur Engineering College, Jabalpur (M.P.), INDIA \\ Email: ankushgupta09.88@gmail.com ${ }^{1}$,rajeevchandak2003@yahoo.com², mkkgec@ gmail.com ${ }^{3}$ \\ Received Nov'28, 2019; received in revised form Jan'23, 2020; Accepted Jan’23, 2020
}

\begin{abstract}
This paper presents the study of influence of particle size of fine aggregate on the filling ability and segregation resistance of Self - Compacting Concrete (SCC). The filling ability was assessed from the results of mortar spread diameter by mini truncated cone and the segregation resistance was assessed from the results of mini $V$-funnel flow time of mortar fraction of SCC as per EFNARC guidelines at 0,15,30, 45 and 60 minutes of mixing. 8 mixes of mortar fraction of SCC consist of two different cement replacement percentage (CRP) by fly ash are investigated for four different particle sizes of fine aggregate.
\end{abstract}

Key Words- Self-Compacting Concrete; Mortar fraction; Filling ability; Segregation resistance; Spread diameter; V-funnel flow time.

Broad Area- Civil Engineering.

Sub-Area- Structural Engineering.

\section{Introduction}

Self-compacting concrete (SCC) has the ability to flow under its own weight to fill the formwork without external vibration (filling ability) and to retain its homogeneity without segregation or blocking between the coarse aggregate and its mortar fraction while flowing through the heavily congested reinforcement (segregation resistance). The Mortar fraction of concrete comprises of powder, water and air, admixture plus those aggregates less than $4 \mathrm{~mm}$ (i.e. fine aggregate) [1-4].

In SCC, the mortar fraction provides lubrication between the coarse aggregate particles and overall stability of the concrete. The mini truncated cone is used to assess the deformability of mortar fraction which is a measure for the filling ability of the concrete and the mini Vfunnel flow time of mortar fraction is used to assess the viscosity which is a measure for the segregation resistance of the concrete.

In present study, the filling ability and the segregation resistance of mortar fraction of SCC to ensure the self-compactability of concrete for casting at $0,15,30,45$ and 60 minutes after mixing is investigated. The weight of all the contents, namely; fine aggregate, superplasticiser dosage, powder and water-powder ratio were kept constant. Mortar mixes with varying size of fine aggregate particle and cement replacement percentage (CRP) by fly ash is studied.

\section{Materials}

\subsection{Cement}

53 grade Ordinary Portland cement was used and conforms to IS 12269- 1987. Its properties are given in Table-1. 
Table 1. Physical Properties of Cement

\begin{tabular}{|c|c|}
\hline Characteristics & Values \\
\hline Normal consistency & $28 \%$ \\
\hline $\begin{array}{c}\text { Setting Time- } \\
\text { Initial set } \\
\text { Final set }\end{array}$ & $\begin{array}{c}99 \text { Min. } \\
184 \mathrm{Min} .\end{array}$ \\
\hline Specific gravity & 3.15 \\
\hline
\end{tabular}

\subsection{Fly ash}

Fly ash and its chemical analysis report is obtained from Sanjay Gandhi thermal power station, Birshingpur Pali, M.P., India. The physical characteristics of fly ash are given in the Table 2 and the chemical properties of fly ash is given in Table 3.

Table 2. Physical properties of fly ash

\begin{tabular}{|c|c|}
\hline $\begin{array}{c}\text { Physical } \\
\text { Properties }\end{array}$ & Test Result \\
\hline Colour & Grey Blackish \\
\hline Specific Gravity & 2.27 \\
\hline
\end{tabular}

Table 3. Chemical Properties of fly ash

\begin{tabular}{|c|c|}
\hline Elemental Oxides & Percentage \\
\hline Silicon Di-oxide & $63.41 \%$ \\
\hline Aluminium oxide & $25.88 \%$ \\
\hline Calcium Oxide & $0.34 \%$ \\
\hline Magnesium Oxide & $1.13 \%$ \\
\hline Manganese oxide & None detected \\
\hline Sodium Oxide & $1.19 \%$ \\
\hline Potassium Oxide & $1.22 \%$ \\
\hline Iron Oxide & $3.14 \%$ \\
\hline $\begin{array}{c}\text { Phosphorus } \\
\text { Pentoxide }\end{array}$ & $1.65 \%$ \\
\hline
\end{tabular}

\begin{tabular}{|c|c|}
\hline Sulphur Trioxide & $0.53 \%$ \\
\hline Titanium Di-oxide & $1.51 \%$ \\
\hline
\end{tabular}

\subsection{Chemical Admixtures}

Conplast SP430 confirms to ASTM-C-494 Type "F" was used as superplasticiser. It is based on Sulphonated Napthalene polymers. The properties of Conplast SP430 are given in Table 4.

Table 4. Properties of Conplast SP430

\begin{tabular}{|c|c|}
\hline Specific gravity & 1.220 to 1.225 at $30^{\circ} \mathrm{C}$ \\
\hline Chloride content & Nil \\
\hline Air entrainment & $\begin{array}{c}\text { Approx } 1 \% \text { additional } \\
\text { air is entrained }\end{array}$ \\
\hline
\end{tabular}

\subsection{Water}

Tap water available in the college laboratory was used.

\subsection{Fine Aggregate}

The sand confirming to IS 650: 1966 was used as fine aggregate. The physical characteristics of sand are given in the Table 5. Four fine aggregates, based on particle sizes (PS) were analyzed, viz.

Particle size 1 in between $90 \mu$ to $300 \mu$, denoted as $90 \mu<$ PS- $1<300 \mu$.

Particle size 2 in between $300 \mu$ to $500 \mu$, denoted as $300 \mu<$ PS- $2<500 \mu$.

Particle size 3 in between $500 \mu$ to $710 \mu$, denoted as $500 \mu<$ PS-3< $710 \mu$.

Particle size 4 in between $710 \mu$ to $1 \mathrm{~mm}$, denoted as $710 \mu<$ PS- $4<1 \mathrm{~mm}$

Table 5. The physical characteristics of sand Physical characteristics of sand

\begin{tabular}{|l|l|}
\hline Colour & Grayish White \\
\hline Specific Gravity & 2.64 \\
\hline
\end{tabular}




\begin{tabular}{|l|l|}
\hline Absorption in 24 hours & $0.80 \%$ \\
\hline Shape of grains & Sub angular \\
\hline
\end{tabular}

\section{Experimental procedure for SCC Mortar}

\subsection{Mortar Spread test}

In this test, the truncated cone is placed in the centre of a plate in the same position as indicated in Figure 1. The cone is fully filled with mortar and then lifted immediately so that the mortar spreads over the plate. The spread diameters are thereafter measured when the mortar flow completely stopped.

The spread tests were conducted by truncated cone, on the mortar fraction of SCC with two different cement replacement percentage (CRP) by fly ash and four different particle sizes of fine aggregate at an elapsed time 0, 15, 30, 45 and 60 minutes after mixing. In this test, the average mortar spread diameter was calculated as-

Average spread diameter, $\mathbf{S}=\left(\mathrm{d}_{\text {perp }}+\mathrm{d}_{\max }\right) / 2$, where, $\mathbf{d}_{\max }$ is the maximum diameter and $\mathbf{d}_{\text {perp }}$ is the diameter perpendicular to $\mathbf{d}_{\max }$ of mortar spread by truncated cone.

The values of spread diameter ' $\mathrm{S}$ ' ( $\mathrm{mm})$ is used to assess the deformability which is a measure for the filling ability of the concrete.

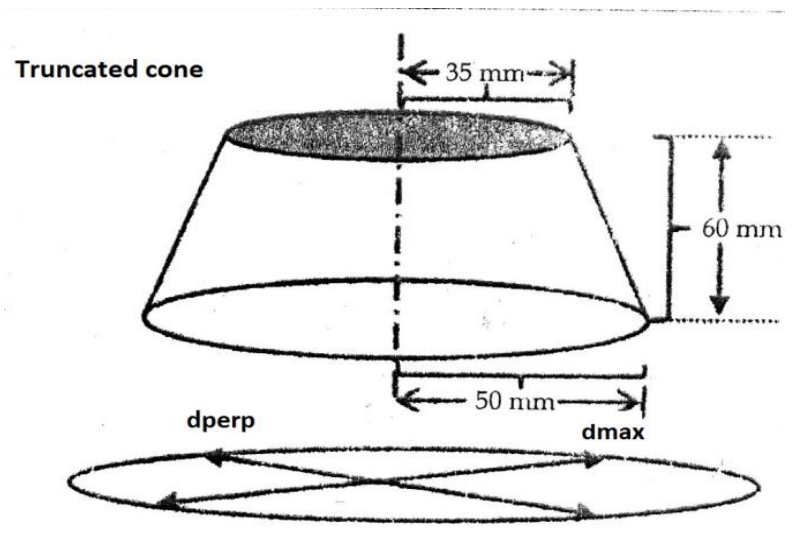

Figure 1 Details of Truncated Cone for Mortar Spread Test
(Courtesy: Elinwa, A. U., \& Mamuda, A. M. (2014). Sawdust ash as powder material for self-compacting concrete containing naphthalene sulfonate. Advances in Civil Engineering, 2014).

\subsection{V-Funnel test}

The mortar flow tests were conducted by Vfunnel as shown in the Figure 2. On the mortar fraction of SCC with two different cement replacement percentage (CRP) by fly ash and four different particle sizes of fine aggregate at an elapsed time $0,15,30,45$ and 60 minutes after mixing.

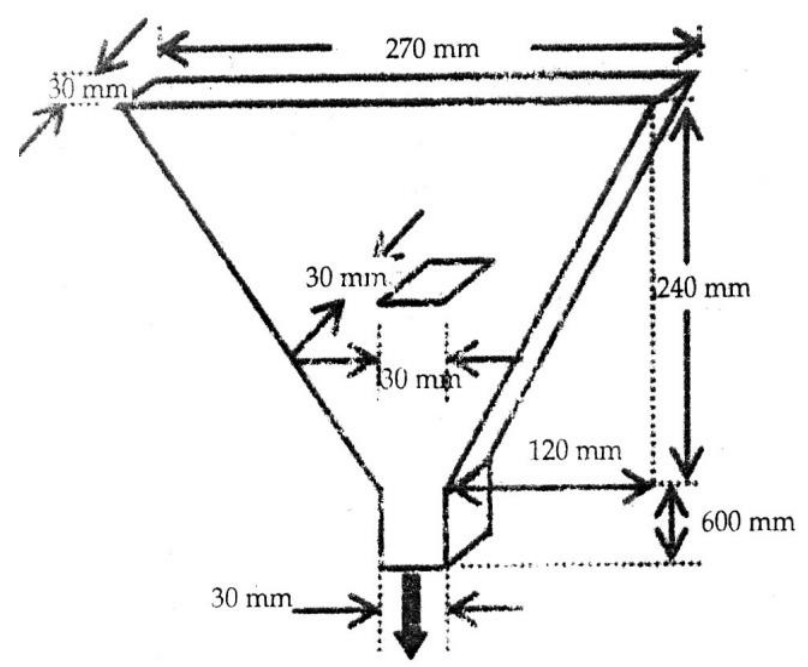

Figure 2. Details of V Funnel for Mortar V Funnel test

In this test, the mortar flow time ' $\mathrm{t}_{0}$ ' ( $\mathrm{sec}$ ) due to its self-weight, measured immediately after placing the mortar in the funnel as the period from releasing the gate until first light enters the opening gap was recorded. The values of flow time ' $t_{0}$ ' ( $\mathrm{sec}$ ) is used to assess the viscosity which is a measure for the segregation resistance of the concrete.

\section{Mortar Mix Proportions}

Table- 6 gives the mortars proportion details. The mortar mixtures contain powder which composed of two weight proportions of OPC and fly ash, i.e. $80: 20,70: 30$. The water-powder ratio $(\mathrm{w} / \mathrm{p})$ 
was 0.3 by weight and superplasticiser dosage was 1.5 percent by weight of powder. This w/p ratio and the superplasticiser dosage were decided to achieve a reasonable spread and flow time.

\section{Results}

Results of $\mathrm{V}$ funnel flow time $\mathrm{t}_{0}(\mathrm{sec})$ and Average spread diameter S (mm) for SCC mortar mix proportions are given in table 7 at different elapsed time after mixing i.e. $0,15,30,45$ and 60 minutes.

\subsection{Analysis and discussion of results}

In the present study, the influence of particle size of fine-aggregate on the filling ability and the segregation resistance of self- compacting concrete is assessed. Since the quality, quantity and the grading of coarse aggregate was kept constant, therefore the rheological properties of mortar fraction (i.e. deformability and viscosity) highlights the filling ability and the segregation resistance potential of Self-compacting concrete. Very good deformability of mortar fraction of SCC is required for maintaining the selfcompactability of concrete at casting, so that the concrete will be able to fill every corner of formwork under its self-weight in the absence of any external vibration. Also, very low viscosity will increase the segregation when concrete passes through the dense reinforcement, on the other hand excessive viscosity will impair the pumping and placing of the concrete. So, there is a need for optimum combination of deformability and viscosity to ensure better self-compactability of concrete at casting.

Table 6. SCC mortar mix proportions

\begin{tabular}{|c|c|c|c|c|c|c|c|c|c|c|}
\hline \multirow{2}{*}{$\begin{array}{c}\text { Mortar } \\
\text { Mix } \\
\text { Designati } \\
\text { on }\end{array}$} & \multirow{2}{*}{$\begin{array}{l}\text { Particle Size of } \\
\text { fine aggregate }\end{array}$} & \multicolumn{3}{|c|}{ Powder 'p' (2 kg) } & \multirow{2}{*}{$\begin{array}{c}\text { Water } \\
0.3 \times \text { p } \\
\text { (litre) }\end{array}$} & \multirow{2}{*}{$\begin{array}{c}\operatorname{admix} . \\
(1.5 \%) \\
(\mathrm{kg})\end{array}$} & \multicolumn{4}{|c|}{ fine aggregate $(3 \mathrm{~kg})$} \\
\hline & & $\begin{array}{c}\text { OP } \\
\text { C } \\
(\mathrm{kg})\end{array}$ & $\begin{array}{l}\text { Fly } \\
\text { ash } \\
(\mathbf{k g})\end{array}$ & Ratio & & & $\begin{array}{c}\text { PS- } \\
1\end{array}$ & PS-2 & PS-3 & PS-4 \\
\hline PS-1/20 & $90 \mu<\mathrm{PS}<300 \mu$ & 1.60 & 0.40 & $80: 20$ & 0.600 & 0.030 & $3 \mathrm{~kg}$ & & & \\
\hline $\mathrm{PS}-2 / 20$ & $300 \mu<\mathrm{PS}<500 \mu$ & 1.60 & 0.40 & $80: 20$ & 0.600 & 0.030 & & $3 \mathrm{~kg}$ & & \\
\hline PS-3/20 & $500 \mu<P S<710 \mu$ & 1.60 & 0.40 & $80: 20$ & 0.600 & 0.030 & & & $3 \mathrm{~kg}$ & \\
\hline PS-4/20 & $710 \mu<P S<1 \mathrm{~mm}$ & 1.60 & 0.40 & $80: 20$ & 0.600 & 0.030 & & & & $3 \mathrm{~kg}$ \\
\hline PS-1/30 & $90 \mu<\mathrm{PS}<300 \mu$ & 1.40 & 0.60 & $70: 30$ & 0.600 & 0.030 & $3 \mathrm{~kg}$ & & & \\
\hline PS-2/30 & $300 \mu<P S<500 \mu$ & 1.40 & 0.60 & $70: 30$ & 0.600 & 0.030 & & $3 \mathrm{~kg}$ & & \\
\hline PS-3/30 & $500 \mu<P S<710 \mu$ & 1.40 & 0.60 & $70: 30$ & 0.600 & 0.030 & & & $3 \mathrm{~kg}$ & \\
\hline PS-4/30 & $710 \mu<\mathrm{PS}<1 \mathrm{~mm}$ & 1.40 & 0.60 & $70: 30$ & 0.600 & 0.030 & & & & $3 \mathrm{~kg}$ \\
\hline
\end{tabular}

Mortar mix with sand PS -1 and $20 \%$ cement replacement percentage (CRP) by fly ash designated as PS-1/20

Mortar mix with sand PS -2 and $20 \%$ cement replacement percentage (CRP) by fly ash designated as PS-2/20

Mortar mix with sand PS -3 and $20 \%$ cement replacement percentage (CRP) by fly ash designated as PS-3/20

Mortar mix with sand PS -4 and $20 \%$ cement replacement percentage (CRP) by fly ash designated as PS-4/20 
Mortar mix with sand PS -1 and $30 \%$ cement replacement percentage (CRP) by fly ash designated as PS-1/30

and so on....

As the mortar spread diameter increases, the deformability of the mortar fraction of SCC increases, the greater is the ability of the concrete to fill the formwork under its self-weight at casting, i.e. it's filling ability increases and vice-versa. As the Vfunnel flow time increases, the viscosity of the mortar fraction of SCC increases, which indicate an increase in the segregation resistance of SCC and vice versa. In this study, the weight of all the contents, namely; fine aggregate, superplasticiser dosage, powder and water-powder ratio were kept constant. Mortar mixes with varying size of fine aggregate particle and cement replacement percentage (CRP) by fly ash is studied.

Table 7. Results of $\mathrm{V}$ funnel flow time to $(\mathrm{sec})$ and Average spread diameter $\mathrm{S}(\mathrm{mm})$

\begin{tabular}{|c|c|c|c|c|c|c|c|c|c|c|}
\hline \multirow{2}{*}{$\begin{array}{l}\text { Mortar mix } \\
\text { designation }\end{array}$} & \multicolumn{2}{|c|}{ @0 min } & \multicolumn{2}{|c|}{$@ 15$ min } & \multicolumn{2}{|c|}{ @30 min } & \multicolumn{2}{|c|}{ @ 45 min } & \multicolumn{2}{|c|}{ @60 min } \\
\hline & $\begin{array}{c}\mathrm{t}_{0} \\
(\mathrm{sec})\end{array}$ & $\begin{array}{c}\mathrm{S} \\
(\mathrm{mm})\end{array}$ & $\begin{array}{c}\mathrm{t}_{0} \\
(\mathrm{sec})\end{array}$ & $\begin{array}{c}\mathrm{S} \\
(\mathrm{mm})\end{array}$ & $\begin{array}{c}\mathrm{t}_{0} \\
(\mathrm{sec})\end{array}$ & $\begin{array}{c}\mathrm{S} \\
(\mathrm{mm})\end{array}$ & $\begin{array}{c}\mathrm{t}_{0} \\
(\mathrm{sec})\end{array}$ & $\begin{array}{c}\mathrm{S} \\
(\mathrm{mm})\end{array}$ & $\begin{array}{c}\mathrm{t}_{0} \\
(\mathrm{sec})\end{array}$ & $\begin{array}{c}\mathrm{S} \\
(\mathrm{mm})\end{array}$ \\
\hline PS-1/20 & 10.1 & 220 & 11.2 & 210 & 12.1 & 190 & 12.8 & 170 & 13.4 & 160 \\
\hline PS-2/20 & 9.3 & 235 & 10.6 & 230 & 11.3 & 220 & 12.2 & 210 & 12.5 & 175 \\
\hline PS-3/20 & 8.6 & 250 & 9.7 & 240 & 10.2 & 230 & 11.1 & 225 & 11.7 & 205 \\
\hline PS-4/20 & 7.9 & 260 & 8.8 & 250 & 9.6 & 245 & 10.4 & 240 & 10.6 & 220 \\
\hline PS-1/30 & 9.2 & 235 & 10.3 & 220 & 11.1 & 200 & 11.8 & 180 & 12.3 & 165 \\
\hline PS-2/30 & 8.6 & 250 & 9.5 & 245 & 10.6 & 240 & 11.2 & 215 & 11.7 & 185 \\
\hline PS-3/30 & 8.1 & 265 & 8.9 & 255 & 9.3 & 250 & 9.8 & 245 & 10.2 & 240 \\
\hline PS-4/30 & 7.6 & 280 & 8.4 & 270 & 8.7 & 270 & 9.3 & 255 & 9.5 & 250 \\
\hline
\end{tabular}

\subsection{Graphical representations of results}

The graph of mortar spread diameter ' $\mathrm{S}$ ' $(\mathrm{mm}) \mathrm{v} / \mathrm{s}$ different elapsed time after mixing are given in figure 3. \& figure 5. and mortar flow test results showing the ' $\mathrm{t}_{0}$ '(in seconds) measured immediately after placing the mortar mix in the $\mathrm{V}$ - funnel, for different mortar mixes v/s different elapsed time after mixing are given in figure 4 . \& figure 6.

EFNARC [1] (European federation of national trade associations representing producers and applicators of specialist building products) recommends the acceptable values for mortar fraction of SCC, for the spread diameter between $240 \mathrm{~mm}$ to $260 \mathrm{~mm}$ which highlights the optimum filling ability and V- funnel flow time between 7 to 11 seconds which highlights the optimum segregation resistance to ensure selfcompactability of concrete at casting.

The following observations can be made from Figure 3 to Figure 6:

1. Mortar mixes with PS-1/20, PS-2/20, and PS$1 / 30$ having unacceptable values of spread diameter less than $240 \mathrm{~mm}$ and/or V-funnel flow time above 11 seconds showing high segregation resistance but low filling ability at all elapsed time after mixing. Therefore, the mix can be judged as unsuitable for SCC.

2. Mortar mix with PS-4/30 having unacceptable values of spread diameter more than $260 \mathrm{~mm}$ and/or $\mathrm{V}$ - funnel flow time 
below 7 seconds showing high filling ability but low segregation resistance at all elapsed time after mixing. Therefore, the mix can be judged as unsuitable for SCC.

3. Mortar mix with PS-3/20,PS-2/30 and PS$4 / 20$ having acceptable values for the spread diameter between $240 \mathrm{~mm}$ to $260 \mathrm{~mm}$ and Vfunnel flow time between 7 to 11 seconds which highlights the optimum filling ability

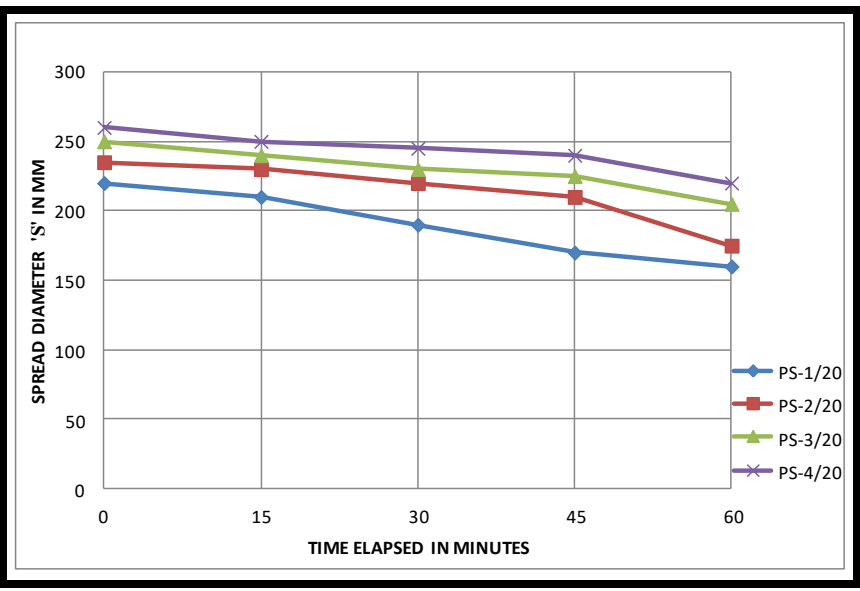

Figure 3. Spread test by truncated cone for CRP $20 \%$

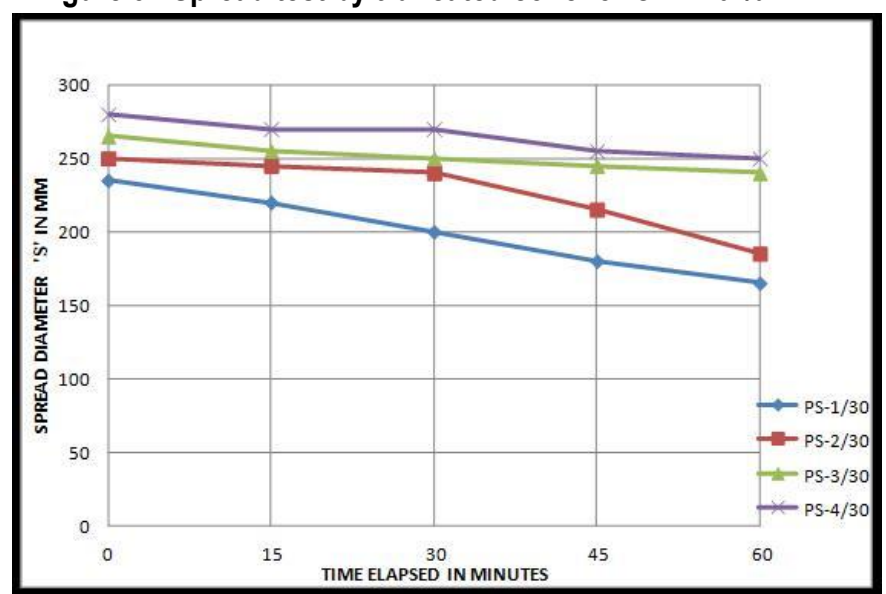

Figure 5. Spread test by truncated cone for CRP $30 \%$

5. As illustrated in the graphs shown in figure 3 and figure 5, the spread diameter ' $\mathrm{S}$ ' increases with the increase in the particle size of fine aggregate for mixes with $20 \%$ \& 30 $\%$ fly ash replacement which indicates increase in filling ability with increase in the particle size of fine aggregate. and segregation resistance to ensure selfcompactability of concrete for casting within 15 minutes,30 minutes and 45 minutes respectively after mixing.

4. Mortar mix with PS-3/30 having optimum filling ability and optimum segregation resistance to ensure better self-compactability of concrete for casting within elapsed time of 60 minutes after mixing.

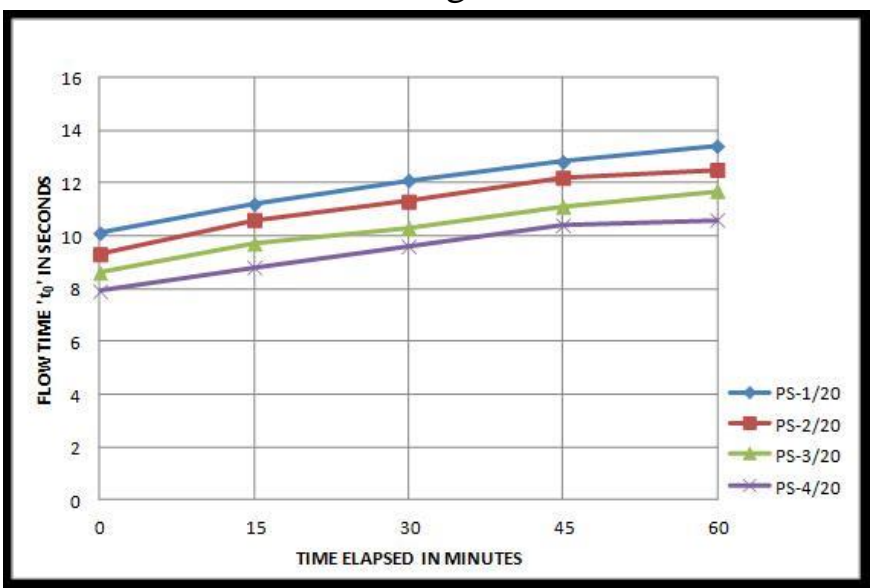

Figure 4. Flow test by V - funnel for CRP 20\%

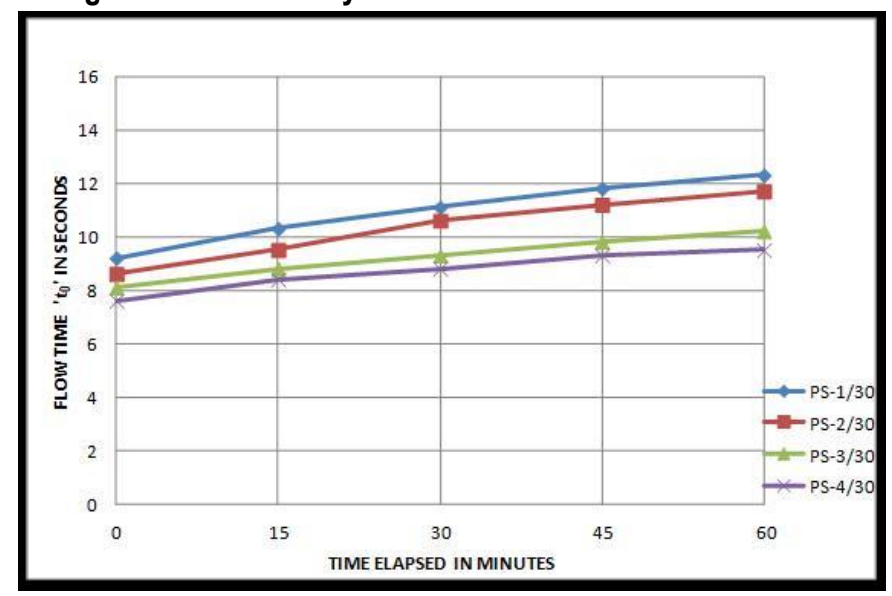

Figure 6. Flow test by V - funnel for CRP $30 \%$

6. As illustrated in the graphs shown in figure 4 and figure 6 , the flow time ' $t_{0}$ ' increases with the decrease in the particle size of fine aggregate for mixes with $20 \%$ \& $30 \%$ fly ash replacement which indicates increase in segregation resistance with decrease in the particle size of fine aggregate. 
7. By increasing the fly ash percentage i.e. from $20 \%$ to $30 \%$, the spread diameter increases and $\mathrm{V}$ - funnel flow time decreases at all elapsed time for all particle sizes of fine aggregate. This indicates the increase in the filling ability with decrease in the segregation resistance with increase in the fly ash percentage.

\section{Conclusion}

Based on the experimental results for the study of influence of fine aggregate particle size on the filling ability and the segregation resistance of SCC, it is found that -

1. The filling ability of mixes increased and the segregation resistance decreased with the increasing fly ash dosages.

2. The finer particles of fine aggregate reduce the filling ability and increase the segregation resistance. However, the coarser particles of fine aggregate increase the filling ability and decrease the segregation resistance.

Thus, we can conclude that the filling ability and the segregation resistance of an SCC can be controlled by varying particle size of fine aggregate and also by varying the cement replacement percentage by fly ash.

\section{Acknowledgment}

Er. Ankush Gupta, M.E. (Structural Engg.), is grateful to his guide Dr. Rajeev Chandak (Professor \& HOD) and Prof. M. K. Koshta (Associate Professor), Department of Civil Engineering, Jabalpur Engineering College, Jabalpur, who spent their valuable time for giving encouragement, invaluable advice and guidance throughout this research work.

\section{Conflict of interest}

The author declares no conflict of interest.

\section{References}

[1] "Specification and guidelines for SelfCompacting concrete", EFNARC, U.K., February 2002.

[2] Murthy, N. K., Rao, N., Reddy, I. R., \& Reddy, M. V. S. (2012). Mix Design procedure for self-compacting concrete. IOSR Journal of Engineering, 2(9), 33-41.

[3] Domone P. 2009. "Proportioning of SelfCompacting concrete - the UCL method", UCL, Department of Civil, Environmental and Geomatic Engineering.

[4] "The European Guidelines for SelfCompacting Concrete Specification, Production and use", EFNARC European project group, May 2005.

[5] Chowdhury S., Kadam S. and Keskar S. 2011. "Impact of fine aggregate Particle size on rheology and compressive strength of mortar for SCC", The Indian Concrete Journal, 85(4) 51-59.

[6] "Methods of physical tests for hydraulic cement", IS 4031: 1988, Bureau of Indian standards, New Delhi, India, 1988.

[7] "Specification for standard sand for testing of cement, IS 650: 1966", Bureau of Indian standards, New Delhi, India, 1966. 